\title{
A new satellite-derived glacier inventory for western Alaska
}

\author{
R. LE BRIS, F. PAUL, H. FREY, T. BOLCH \\ Department of Geography, Glaciology, Geomorphodynamics and Geochronology, University of Zürich-Irchel, \\ Winterthurerstrasse 190, CH-8057 Zürich, Switzerland \\ E-mail: rlebris@geo.uzh.ch
}

\begin{abstract}
Glacier inventories provide the baseline data to perform climate-change impact assessment on a regional scale in a consistent and spatially representative manner. In particular, a more accurate calculation of the current and future contribution to global sea-level rise from heavily glacierized regions such as Alaska is much needed. We present a new glacier inventory for a large part of western Alaska (including Kenai Peninsula and the Tordrillo, Chigmit and Chugach mountains), derived from nine Landsat Thematic Mapper scenes acquired between 2005 and 2009 using well-established automated glacier-mapping techniques (band ratio). Because many glaciers are covered by optically thick debris or volcanic ash and partly calve into water, outlines were manually edited in these wrongly classified regions during post-processing. In total we mapped $\sim 8830$ glaciers $\left(>0.02 \mathrm{~km}^{2}\right)$ with a total area of $\sim 16250 \mathrm{~km}^{2}$. Large parts of the area $(47 \%)$ are covered by a few $(31)$ large $\left(>100 \mathrm{~km}^{2}\right)$ glaciers, while glaciers less than $1 \mathrm{~km}^{2}$ constitute only $7.5 \%$ of the total area but $86 \%$ of the total number. We found a strong dependence of mean glacier elevation on distance from the ocean and only a weak one on aspect. Glacier area changes were calculated for a subset of 347 selected glaciers by comparison with the Digital Line Graph outlines from the US Geological Survey. The overall shrinkage was $\sim 23 \%$ between 1948-57 and 2005-09.
\end{abstract}

\section{INTRODUCTION}

In response to global temperature increase, glaciers located in Alaska, as in almost every region of the world, have shown a strong retreat since their Little Ice Age maximum extent, with a more pronounced acceleration during the last decades of the 20th century (Molnia, 2007; WGMS, 2008). To better understand and model the response of glaciers to climate change, global inventories in a digital format are required (e.g. Beedle and others, 2008; Radić and Hock, 2010). In the case of Alaska, the main purpose of an inventory is better quantification of the glacier melt contribution to global sea-level rise (e.g. Kaser and others, 2006; Berthier and others, 2010), as well as the modeling of future changes in water resources (Zhang and others, 2007).

As a contribution to the European Space Agency (ESA) GlobGlacier project (Paul and others, 2009), this study focuses on the generation of accurate glacier inventory data from nine Landsat Thematic Mapper (TM) scenes acquired between 2005 and 2009 for a region with previously poor coverage (from the Chugach to the Chigmit Mountains) in both the World Glacier Inventory (WGI; WGMS, 1989) and the Global Land Ice Measurements from Space (GLIMS) glacier database (Raup and others, 2007). In a previous study, Manley (2008) stressed the importance of putting effort into creating a glacier inventory from already available data compiled by the US Geological Survey (USGS) in the 1950s for the eastern part of the Alaska Range. We have thus decided to use the digitally available version of this earlier glacier survey to assess mean decadal changes in glacier size for a subset of selected glaciers. The new dataset is available through the GLIMS website (www.glims.org).

\section{STUDY REGION AND INPUT DATA}

\subsection{Study region}

The study region is situated around the Gulf of Alaska (Fig. 1), with glaciers ranging in altitude from sea level up to
$4000 \mathrm{~m}$ a.s.l. To provide a more regionalized assessment of glacier inventory data, the region was divided into seven subregions: (1) Tordrillo Mountains, (2) Chigmit Mountains, (3) Fourpeaked Mountain, (4 and 5) south and north Kenai Mountains, (6) Chugach Mountains and (7) Talkeetna Mountains. While the Tordrillo Mountains are situated in the southern part of the Alaska Range, the Chigmit Mountains and Fourpeaked Mountain are also considered to belong to the Aleutian Range and extend south of the Tordrillo Mountains to Kamishak Bay. There are several thousand glaciers in these mountain ranges, representing a large variety of glacier types from small cirques to large valley glaciers with multiple basins (Denton and Field, 1975). Several of the glaciers are classified as surge-type (e.g. Hayes and Harpoon Glaciers) and some of them cover volcanoes (e.g. Crater Glacier on Mount Spurr (3374 m a.s.I.)).

The Kenai Mountains are located on the Kenai Peninsula between Cook Inlet and the Gulf of Alaska. The maximum elevation of glaciers here is $\sim 2000$ ma.s.l., and the three main ice masses are the Sargent and Harding ice fields and an unnamed ice cap. The part of the Chugach Mountains considered here is bounded on the east by the Copper River and on the west by the Knik Arm. Together, these mountain ranges contain about one-third of the glacierized area of Alaska (Post and Meier, 1980). Many large glaciers (e.g. Harvard, Yale, Columbia, Shoup and Valdez glaciers) are of tidewater type and drain into northern Prince William Sound. In the west, until 1966, Knik Glacier dammed the outflow from Lake George, resulting in nearly annual glacier-outburst floods (Post and Mayo, 1971). The Talkeetna Mountains are the final region surveyed in this study. They are located north of the Matanuska River and north of the Chugach Mountains. Many peaks are higher than $2000 \mathrm{~m}$ a.s.l., with a maximum elevation of 2550 ma.s.l. As the entire study region includes glaciers of all types, with highly variable elevation ranges and locations (from the coast to the interior), different climatic regimes and responses to climate change can be expected. 


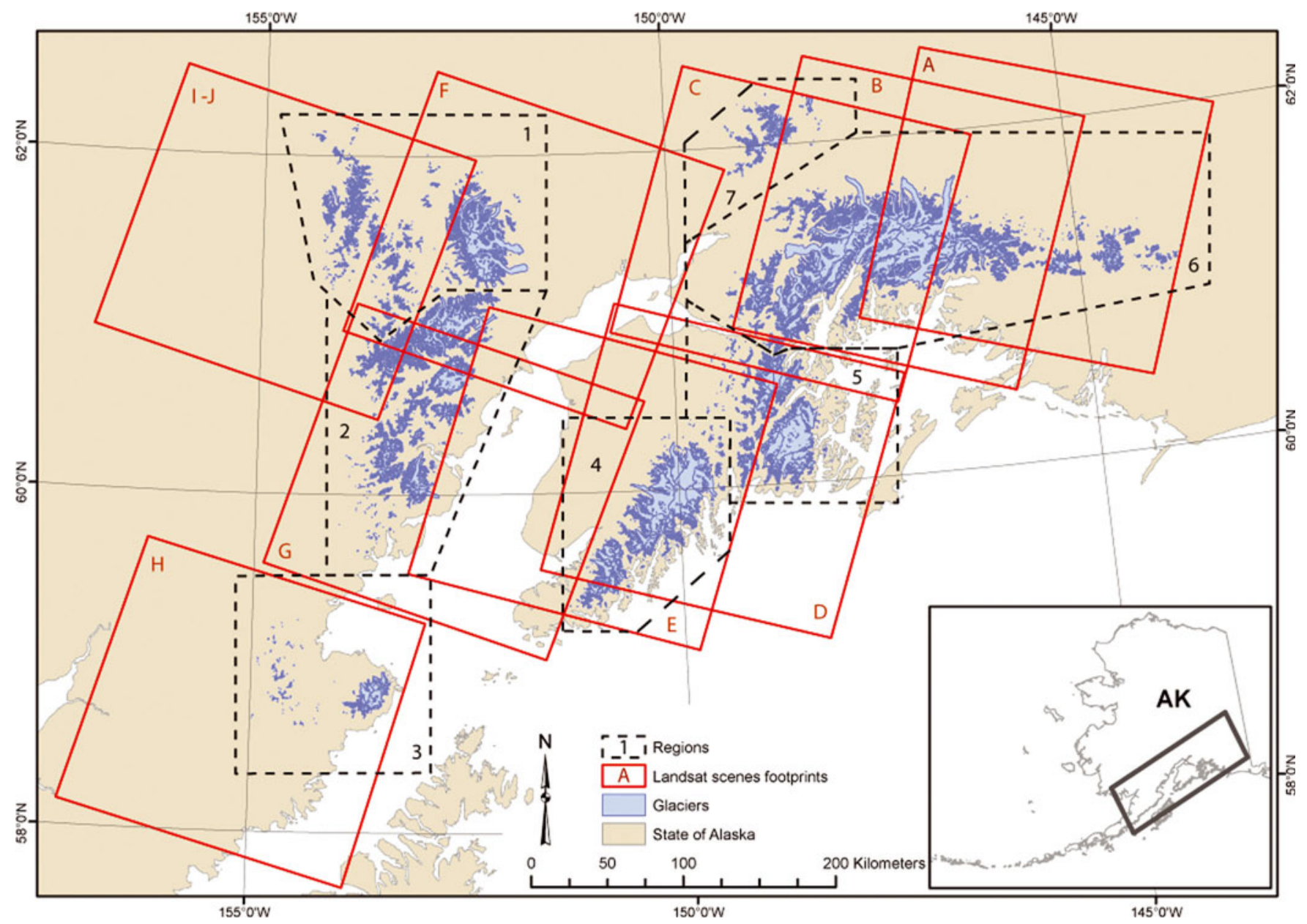

Fig. 1. Location map showing the footprint of the ten Landsat scenes originally analyzed in this study (red squares, where the red letters refer to the scene IDs). The sub-regions are delimited by dashed polygons, with the numbers referring to the IDs (see Tables 1 and 3), and glaciers are in light blue. The location of the study region in Alaska, USA, is shown in the inset.

In general, the study region experiences a predominantly maritime climate near the coast and a more continental climate further inland (e.g. http://climate.gi.alaska.edu). In the maritime region, mountain ranges act as a barrier for the westerlies, resulting in high amounts of annual precipitation along the coast of the Gulf of Alaska and frequent cloud cover. Clouds and frequent seasonal snowfields considerably decrease the number of useful satellite scenes in this region, so the inventory data refer to a 5 year period.

Table 1. List of the Landsat scenes used in the glacier inventory of western Alaska (source: http://glovis.usgs.gov). See Figure 1 for location of footprints; scene B was finally not used

\begin{tabular}{lcccr}
\hline ID & Type & Path & Row & Date \\
\hline A & Landsat 5 TM & 66 & 17 & 6 Sep 2009 \\
B & Landsat 7 ETM+ & 67 & 17 & 1 Aug 2002 \\
C & Landsat 5 TM & 68 & 17 & 3 Aug 2009 \\
D & Landsat 5 TM & 68 & 18 & 12 Sep 2006 \\
E & Landsat 5 TM & 69 & 18 & 9 Jul 2009 \\
F & Landsat 5 TM & 70 & 17 & 28 Aug 2007 \\
G & Landsat 5 TM & 70 & 18 & 28 Aug 2007 \\
H & Landsat 5 TM & 71 & 19 & 14 Sep 2005 \\
I & Landsat 5 TM & 72 & 17 & 20 Aug 2005 \\
J & Landsat 5 TM & 72 & 17 & 26 Aug 2007
\end{tabular}

\subsection{Input data}

We analyzed all Landsat scenes from 1999 to 2009 that are freely available in the glovis.usgs.gov archive and processed to the standard terrain correction (level 1T). We selected ten of them covering our study region (Fig. 1; Table 1).

Scene B (Enhanced TM Plus (ETM+) from 2002) was processed at the beginning of the study, though it had considerable amounts of seasonal snow hiding several glacier boundaries. When two scenes from 2009 (A and C) with much better snow conditions became available we decided to use these for the Chugach Mountains inventory.

For the western Alaska Range (scenes 72-17), we combined two scenes. The scene from 2005 (I) had much better snow conditions (particularly in the accumulation region), but the lower part of most low-lying glacier tongues was barely visible due to a dense layer of fog and/or smog from fire. The lower glacier parts were hence derived from the 2007 scene $(J)$, in large part by manual digitization of the debris-covered tongues.

A digital elevation model (DEM) is required to calculate topographic glacier parameters (e.g. minimum, mean and maximum elevation, mean slope and mean aspect) and to perform hydrological analysis (watersheds) for determination of drainage divides to separate contiguous ice masses into individual glaciers (e.g. Schiefer and others, 2008; Bolch and others, 2010b). For the study region, we used the Advanced Spaceborne Thermal Emission and Reflection 
Radiometer (ASTER) global DEM (GDEM) and the USGS National Elevation Dataset (NED), both with a spatial resolution of $30 \mathrm{~m}$, and for part of the region (south of $60^{\circ} \mathrm{N}$ ) the Shuttle Radar Topography Mission (SRTM) C-band DEM with resolutions of $1^{\prime \prime}(\sim 30 \mathrm{~m}$, SRTM-1) and $3^{\prime \prime}$ ( $\sim 90 \mathrm{~m}$, SRTM-3). The SRTM DEM is known for its accuracy, with a mean deviation from a reference dataset of $\sim 3 \pm 15 \mathrm{~m}$ (Berry and others, 2007). However, it is less accurate in the rough terrain of high mountains, with typical problems of synthetic aperture radar (SAR)-derived DEMs (radar shadow, layover, foreshortening) causing data voids. We thus use the seamless SRTM DEM from the Consultative Group for International Agriculture Research (CGIAR), version 4, where these voids were filled with additional elevation information (http://srtm.csi.cgiar.org). A study comparing SRTM-1 data with NED data in the USA revealed slightly higher accuracy of the SRTM-1 DEM in both the horizontal and vertical directions (Smith and Sandwell, 2003).

The GDEM can be of good accuracy (Hayakawa and others, 2008) but has inaccuracies mainly in regions of steep slopes and snow, due to missing contrast (Frey and Paul, unpublished information), and contains artifacts like local bumps and pits (depressions) which are typical for ASTERderived DEMs (Kääb and others, 2003; Toutin, 2008). However, these artifacts were not a problem for this study. Due to its northern limitation $\left(60^{\circ} \mathrm{N}\right)$, the SRTM DEM was available only for the southern part of the Kenai Peninsula, while the NED and the GDEM cover the entire region. Several tiles of both DEMs were downloaded, mosaicked and reprojected to Universal Transverse Mercator (UTM) zone 5 and bilinearly interpolated to $30 \mathrm{~m}$ cell size. Hillshades were created for all three DEMs to better recognize artifacts. While the NED refers to the contour lines of the related topographic maps from the 1950s, the GDEM was created from all available scenes in the ASTER archive acquired between 1999 and 2007. Hence, the topography in the GDEM fits much better to the acquisition period of the Landsat data (Table 1) and was therefore used to calculate minimum glacier elevation.

The Digital Line Graph (DLG) dataset was utilized to calculate changes in glacier size (see section 3.3). This earlier glacier mapping was compiled by the USGS from the $1: 63360$-scale $15^{\prime \prime}$ topographic quadrangle maps. Because the DLG has been partly updated compared to the Digital Raster Graph (DRG), we only selected glaciers with a good coincidence of the outlines. The DRGs are a scan of the topographic maps that were created from vertical aerial photographs (1948-57) by stereophotogrammetric techniques. For glacier identification we used this DRG dataset from the USGS, the Geographic Names Information Service (GNIS) which is also available in a digital format (http:// geonames.usgs.gov/), the Alaska atlas and gazetteer (DeLorme, 2004) and the recently published Alaska volume of the Satellite image atlas of glaciers of the world (Williams and Ferrigno, 2008).

\section{METHODS}

\subsection{Glacier mapping}

We use automated mapping as the basic method and only edit regions with wrong classification. The glacier-mapping technique is the well-established semi-automated band ratio

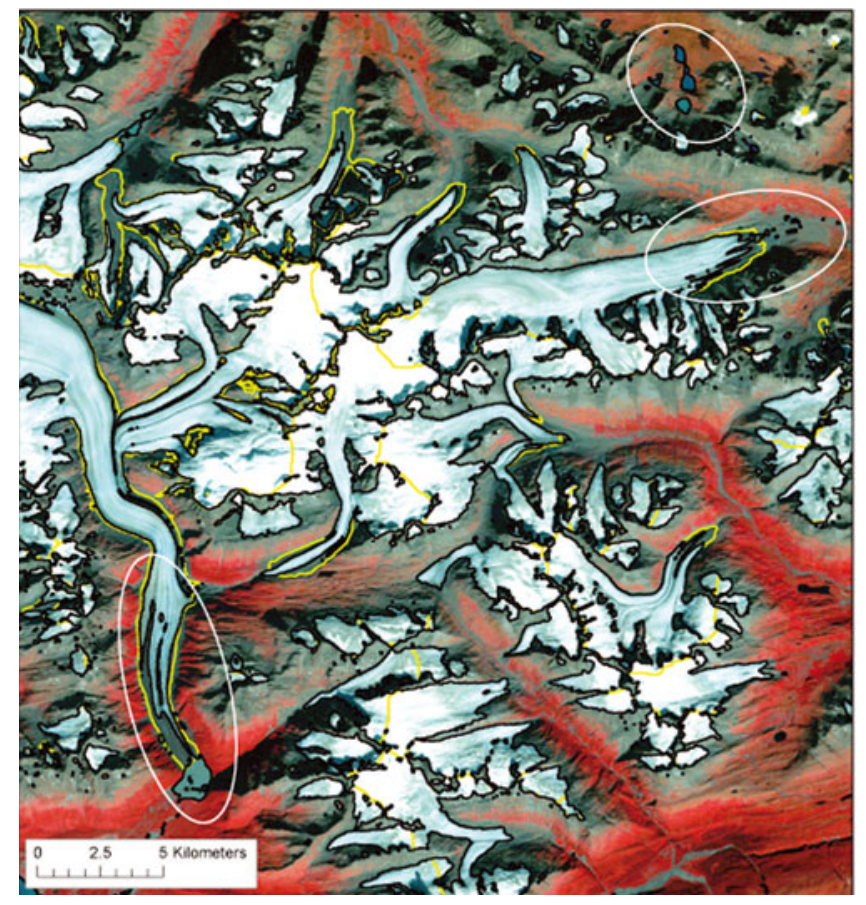

Fig. 2. Raw classification result from the algorithm (black) and manually corrected outlines (yellow) for a small region in the Chugach Mountains (scene A). Circles denote examples of misclassification of water bodies and non-classification of the debriscovered glaciers. A false-color composite (bands 432 as RGB) of the respective Landsat scene is displayed in the background.

method (TM3/TM5) with manual threshold selection (e.g. Paul and Kääb, 2005). This method is based on the specific spectral reflectance properties of snow and ice compared with other terrain. While reflectance of glacier ice and snow in band TM3 (red) is comparably high (with possible sensor saturation over fresh snow), it is very low in band TM5 (shortwave infrared (SWIR)). These spectral differences make the TM3/TM5 ratio very efficient at discriminating glaciers from other terrain. Further advantages of the technique are its reproducibility and consistency for an entire region, and its accuracy for clean to slightly dirty glacier ice (e.g. Albert, 2002; Paul and others, 2003; Andreassen and others, 2008; Bolch and others, 2010a). However, manual corrections are still needed, in particular for debris-covered ice, calving glacier termini and water surfaces. Applying an additional threshold in band TM1 (blue) improves the classification in cast shadow (Paul and Kääb, 2005). Before outlines are edited, a noise filter (low pass $3 \times 3$ median filter) is applied to remove isolated snowpatches and to close local gaps. The classified map is then converted to vector format and imported by Geographic Information System (GIS) software. In a post-processing step, the necessary corrections for clouds, shadow, debris cover and water bodies are applied. To facilitate the interpretation, false-color composite images (e.g. with bands 5, 4 and 3 as red, green and blue) are used in the background. Higher spatial resolution data (e.g. aerial photographs, high-resolution imagery such as from QuickBird and IKONOS in Google Earth ${ }^{\mathrm{TM}}$ ) are also utilized for interpretation of selected glaciers when available. In Figure 2, we show the automatically derived and the corrected glacier outlines for a subset of the Chugach Mountains region. Some critical regions (e.g. debris-cover or water surfaces) are highlighted by circles. 


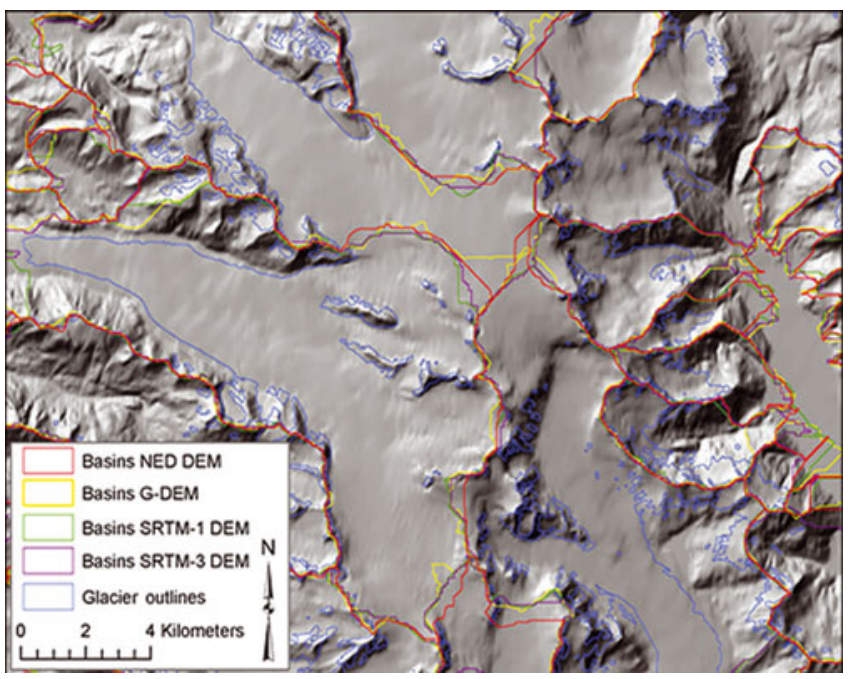

Fig. 3. Comparison of drainage divides derived from the four different DEMs where the background is a shaded relief of the USGS NED.

In the case of the eastern part of the Chugach Mountains, we first processed the Landsat ETM+ scene from 2002, but later two scenes from 2009 with much better snow conditions became available. As a simple update of the previously mapped extent by digital combination of the 2002 and 2009 outlines was not practical, we completely reprocessed the outlines for this region with the latest imagery.

\subsection{Drainage divides}

One of the main outcomes of a glacier inventory is a comprehensive set of topographic parameters for each glacier entity (Paul and others, 2009). A DEM allows us to create the drainage divides required to clip the contiguous ice masses into individual glaciers (e.g. Manley, 2008; Schiefer and others, 2008; Bolch and others, 2010b).

To find the most suitable DEM for calculating the divides, we compared the performance of all four DEMs with each other. In all DEMs the sinks were removed and they were smoothed with a $3 \times 3$ median filter to minimize the effect of possible outliers. Then we applied the approach of Bolch and others $(2010 \mathrm{~b})$ to calculate the divides from the DEMs. For this purpose, a $1 \mathrm{~km}$ buffer is created around all glaciers to constrain the hydrological calculations to this buffer. As this method can generate many artificial and very small polygons in the ablation area, these were selected with a spatial query tool and removed. The resulting drainage divides are similar in all DEMs for distinct mountain ridges (deviation $<100 \mathrm{~m}$ ), although the coarser resolution of the SRTM-3 DEM is recognizable (Fig. 3). Large shifts of the location $(>1000 \mathrm{~m})$ are observed in the flat terrain of the accumulation areas where low contrast in the optical imagery can introduce errors in the DEM (e.g. Svoboda and Paul, 2009; Bolch and others, 2010a). Divides derived by SRTM-1 and SRTM-3 DEMs seemed to be most realistic when visually compared with the satellite data. Larger deviations of the basins as calculated from the GDEM could be attributed to unnatural peaks and sinks which commonly occur in the GDEM (Fig. 3) and which can show a deviation of $> \pm 25 \mathrm{~m}$ compared to the SRTM DEMs (Frey and Paul, unpublished information). In most cases, the ice divides
Table 2. Summary of glacier count and area value per size class for the entire dataset

\begin{tabular}{lrrrr}
\hline Size class & Count & \% by number & $\begin{array}{c}\text { Area } \\
\mathrm{km}^{2}\end{array}$ & \% by area \\
$\mathrm{km}^{2}$ & & & & \\
\hline & & & & \\
\hline 0.1 & 4701 & 53.3 & 211.1 & 1.3 \\
$0.1-0.5$ & 2240 & 25.4 & 520.1 & 3.2 \\
$0.5-1$ & 686 & 7.8 & 487.7 & 3.0 \\
$1-5$ & 856 & 9.7 & 1874 & 11.5 \\
$5-10$ & 132 & 1.5 & 876 & 5.4 \\
$10-50$ & 160 & 1.8 & 3236 & 19.9 \\
$50-100$ & 21 & 0.2 & 1444 & 8.9 \\
$>100$ & 31 & 0.4 & 7601.1 & 46.8 \\
Total & $\mathbf{8 8 2 7}$ & $\mathbf{1 0 0 . 0}$ & $\mathbf{1 6 2 5 0}$ & $\mathbf{1 0 0 . 0}$ \\
& & & & \\
\hline
\end{tabular}

varied by $<500 \mathrm{~m}$ in the accumulation regions. We finally selected the NED DEM because it covered the entire study region and performed slightly better than the GDEM.

Visual inspection was used to further improve the resulting divides, especially in the accumulation area where anomalies in the NED DEM also occur. A hillshade raster, a flow direction grid, topographic maps and false-color composites are used additionally for this purpose. After intersection of the drainage divides with the glacier outlines, topographic glacier inventory parameters were calculated for each glacier entity from the NED DEM following Paul and others (2009). As mentioned above, minimum elevation was derived from the ASTER GDEM.

\subsection{Change assessment}

To use the glacier outlines from the DLG for calculation of size changes, we first adjusted the drainage divides created for the glacier inventory to the DLG outlines and then used them to separate the contiguous ice masses. We then manually selected a subset of 347 glaciers in the seven subregions that are suitable to assess area changes. To be suitable, the glaciers in both datasets must be clearly identifiable, which is often not the case (see section 5.2). Because the large glaciers are often calving (in lakes) or are of tidewater type, the resulting selection contains relatively 'smaller' glaciers, the largest one being $68 \mathrm{~km}^{2}$. For most of the glaciers, the dates to which the DLG outlines refer were obtained from Berthier and others (2010) or directly from the USGS 1:63000 topographic maps. Because the available DLG outlines have been partly updated, we visually controlled that the selected glaciers were in good agreement with the extents visible on the map (DRG). We are aware that the DLG outlines come with some (maybe systematic) uncertainty, but we think it is worth using them in this study as also recommended by Manley (2008).

\section{RESULTS}

The glacier inventory of western Alaska includes 8827 glaciers larger than $0.02 \mathrm{~km}^{2}$ and covers a total area of $\sim 16250 \mathrm{~km}^{2}$ (Table 2). The $31(0.4 \%)$ glaciers larger than $100 \mathrm{~km}^{2}$ account for $47 \%$ of the total area, while the 7627 glaciers $(86 \%)$ smaller than $1 \mathrm{~km}^{2}$ account for only $7.5 \%$ of the area. These percentages vary with the specific mountain range analyzed, but the general picture is similar in all 


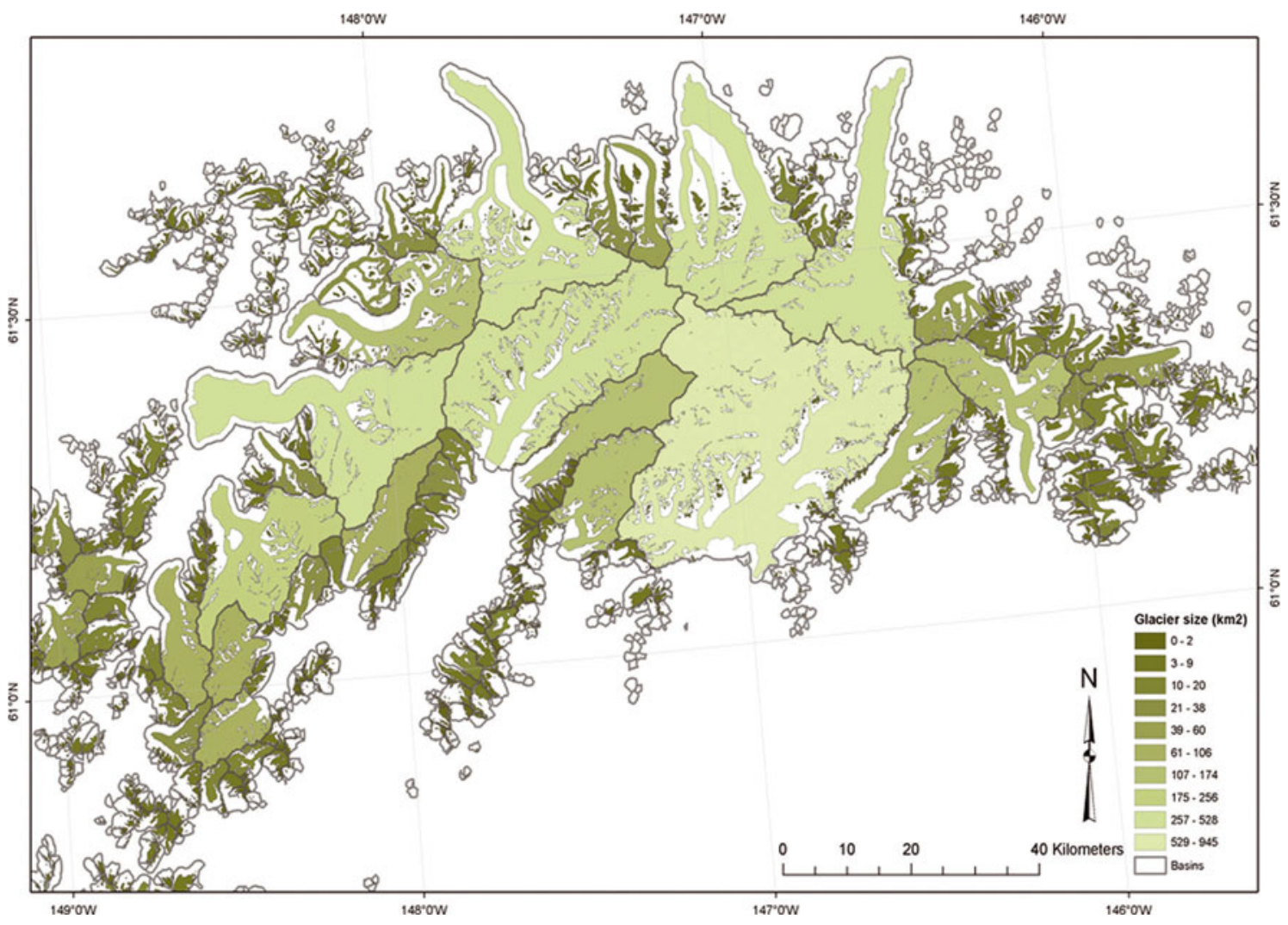

Fig. 4. Color-coded illustration of the glacier size distribution in the Chugach Mountains. Thick lines represent the basins.

regions. The strong contrast in the number and size contribution is visualized for the Chugach Mountains in Figure 4. The largest glaciers are also located in this region, but some are also found in the Kenai Peninsula and the Tordrillo Mountains (Table 3). This table also provides selected parameters from the inventory for the ten largest glaciers. Three of these huge glaciers are land-terminating, while seven are calving into lakes or the ocean. In Table 4 the number and area covered for the seven sub-regions is listed along with the mean glacier size in each region. While four regions have an ice cover between 1900 and $2700 \mathrm{~km}^{2}$, that in the Chugach Mountains region is nearly $6500 \mathrm{~km}^{2}$, while in the two smallest regions (Fourpeaked Mountain and Talkeetna Mountains) it is $\sim 340 \mathrm{~km}^{2}$. On the other hand, the mean size of the glaciers in each region is similar for five regions $\left(1.1-1.8 \mathrm{~km}^{2}\right)$ and only slightly larger for the south
Kenai Peninsula and the Chugach Mountains (2.3 and $2.6 \mathrm{~km}^{2}$ ). This indicates that a region with comparably large glaciers is always accompanied by a proportionally higher number of small glaciers.

Figure 5 shows the area-elevation distribution for the seven sub-regions with $100 \mathrm{~m}$ binning. While most (84\%) of the ice is located between 600 and $2000 \mathrm{~m}$ a.s.I., the glaciers in the Chugach Mountains have an elevation range from sea level to almost $4000 \mathrm{~m}$. The much higher mean elevation of the glaciers in the more continental regions, Tordrillo and Talkeetna, is clearly visible. The different curves thus reflect the differences in the topoclimatic conditions.

Mean elevation of a glacier can be seen as a proxy for the equilibrium-line altitude (ELA) that represents balancedbudget conditions (e.g. Braithwaite and Raper, 2009). It is also a proxy for the climatic conditions in a region,

Table 3. The ten largest glaciers in the study region (sorted by size) with some topographic parameters

\begin{tabular}{|c|c|c|c|c|c|c|c|}
\hline No. & Glacier name & Sub-region & $\begin{array}{l}\text { Area } \\
\mathrm{km}^{2}\end{array}$ & Year & $\begin{array}{c}\text { Mean elevation } \\
\text { m }\end{array}$ & Mean slope & $\begin{array}{l}\text { Mean aspect } \\
{ }^{\circ} \text { east of north }\end{array}$ \\
\hline 1 & Columbia & Chugach Mtns & 945.4 & 2009 & 1426 & 10.4 & 279.8 \\
\hline 2 & Harvard & Chugach Mtns & 528.2 & 2009 & 1821 & 18.9 & 290.3 \\
\hline 3 & Knik & Chugach Mtns & 441.5 & 2009 & 1599 & 8.8 & 1.5 \\
\hline 4 & Chenega & North Kenai Peninsula & 392.2 & 2006 & 1005 & 7.4 & 94.1 \\
\hline 5 & Tazlina & Chugach Mtns & 384.7 & 2009 & 1510 & 6.3 & 23.8 \\
\hline 6 & Nelchina & Chugach Mtns & 337.6 & 2009 & 1781 & 9.7 & 30.5 \\
\hline 7 & Tustumena & South Kenai Peninsula & 336.5 & 2006 & 1202 & 5.3 & 10.4 \\
\hline 8 & Triumvirate & Tordrillo Mtns & 333.2 & 2007 & 1533 & 11.2 & 147.6 \\
\hline 9 & Matanuska & Chugach Mtns & 319.1 & 2009 & 1961 & 12.0 & 29.4 \\
\hline 10 & Blockade & Chugach Mtns & 256.0 & 2007 & 1291 & 8.2 & 86.4 \\
\hline
\end{tabular}




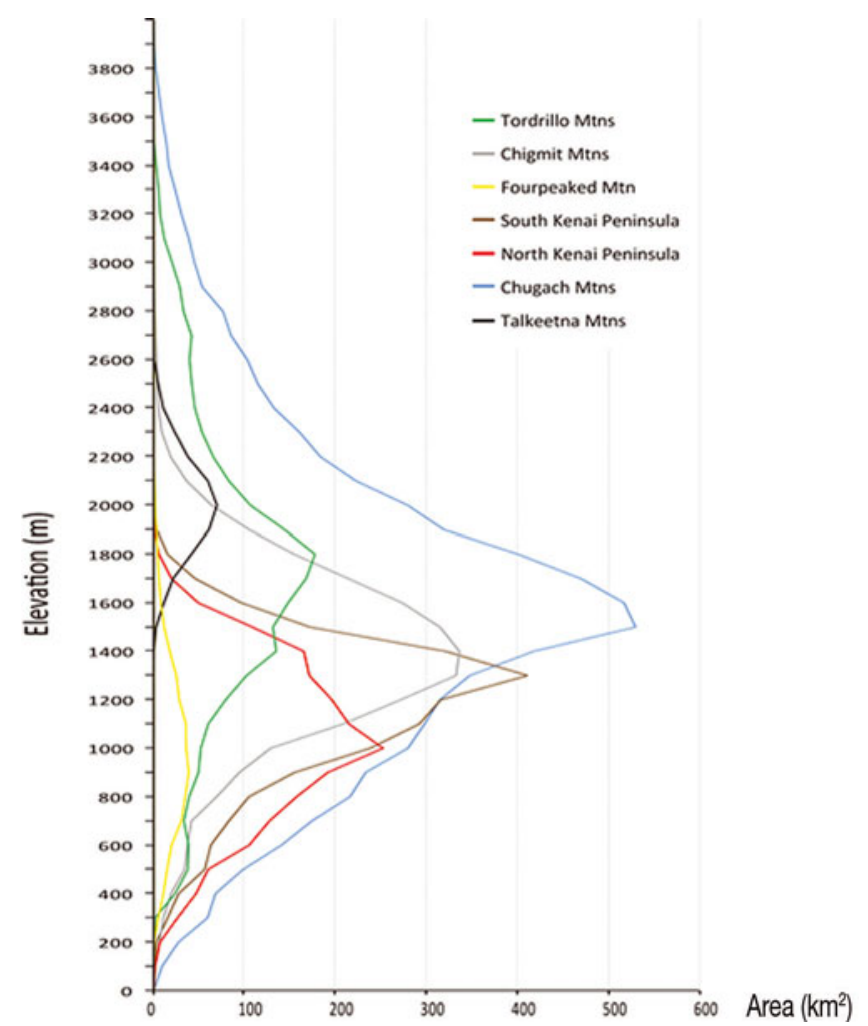

Fig. 5. Glacier area-elevation distribution (hypsography) for the seven sub-regions (see Fig. 1 for location) with $100 \mathrm{~m}$ binning.

especially precipitation amounts. The spatial analysis of this parameter reveals a strong increase from $\sim 100 \mathrm{~m}$ at the coast to 3000 ma.s.l. in the interior (Fig. 6). To give this visual interpretation more weight, we defined an arbitrary point in the Gulf of Alaska that is located at the end of two sector lines enclosing the region (753200, 655100; World
Table 4. Summary of glacier value per sub-region. Region names are from DeLorme (2004)

\begin{tabular}{lcrrc}
\hline Region ID & Region name & Count & $\begin{array}{r}\text { Area } \\
\mathrm{km}^{2}\end{array}$ & $\begin{array}{c}\text { Mean size } \\
\mathrm{km}^{2}\end{array}$ \\
& & & & \\
\hline 1 & Tordrillo Mtns & 1672 & 1998.4 & 1.2 \\
2 & Chigmit Mtns & 1971 & 2778.0 & 1.4 \\
3 & Fourpeaked Mtn & 280 & 329.4 & 1.2 \\
4 & South Kenai Peninsula & 1051 & 2408.3 & 2.3 \\
5 & North Kenai Peninsula & 1079 & 1900.9 & 1.8 \\
6 & Chugach Mtns & 2466 & 6491.8 & 2.6 \\
7 & Talkeetna Mtns & 308 & 343.1 & 1.1 \\
\hline
\end{tabular}

Geodetic System 1984 (WGS84) UTM zone 5N), and calculated the distance from each glacier to this point. A linear regression yields a high correlation $\left(R^{2}=0.91\right.$; significance level ( $p$ value) 0.003 ) between this distance (100$500 \mathrm{~km}$ ) and the mean elevation (1000 to nearly $2000 \mathrm{~m}$ ). This regional trend has of course a high local variability, indicating that changes in temperature and/or precipitation will affect each glacier differently. We have also analyzed the variation of mean elevation with aspect sector for each sub-region (Fig. 7). Apart from the already described increase of mean elevation with distance from the coast, the graph reveals only a small variability with aspect sector (in the mean) in each region, indicating little dependency on this factor. This suggests that the precipitation regime has a much stronger influence on mean elevation in this region than received radiation, at least for the overall trend. On a more regional scale, glacier aspect can also have a more dominant influence on mean elevation (Evans, 2006).

In Figure 8 the relative change in glacier area per decade versus glacier size is illustrated for the subsample of

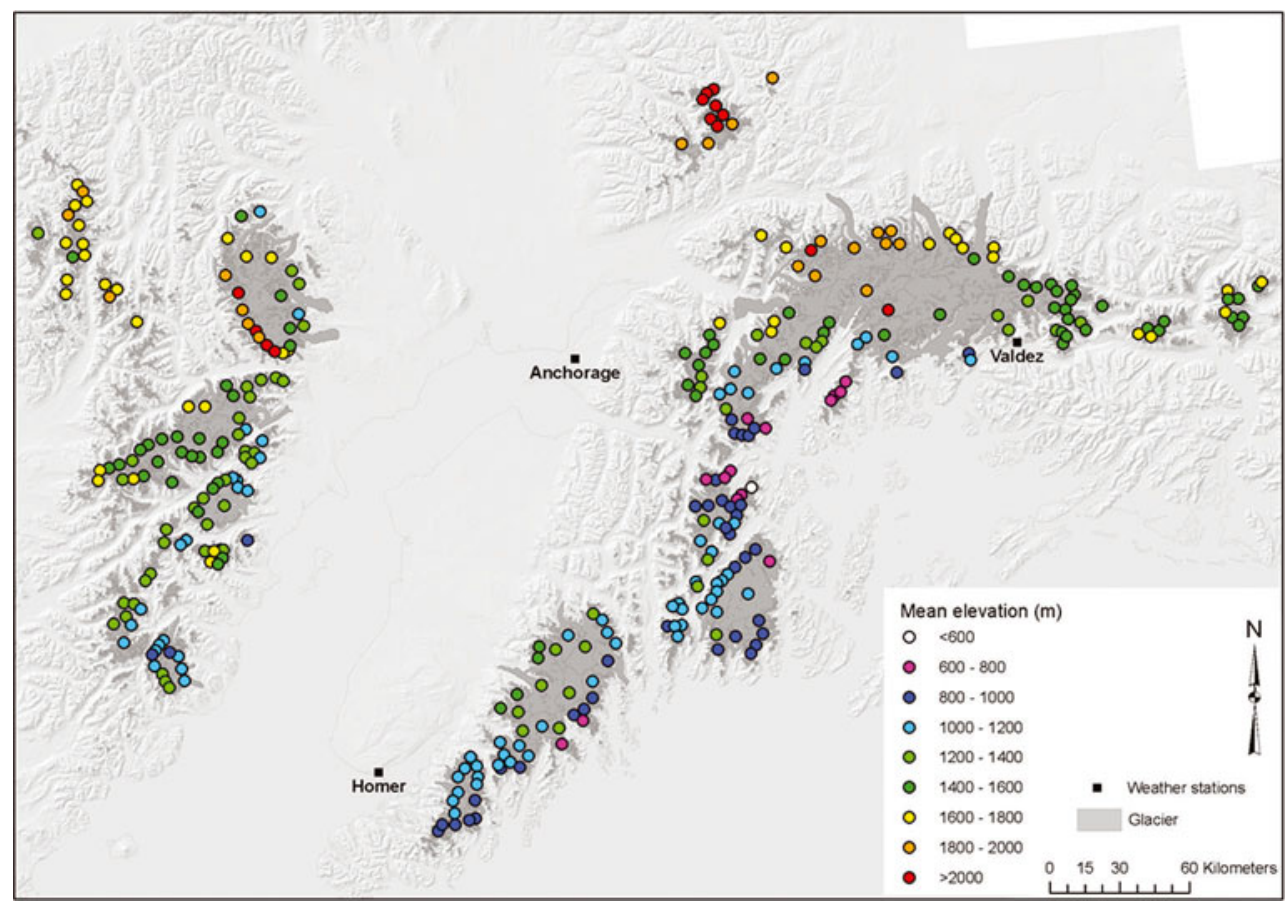

Fig. 6. Spatial variability of mean elevation with size for glaciers larger than $5 \mathrm{~km}^{2}$ over the entire study region. Glaciers are in light grey, and in the background is a shaded relief from the USGS NED. Weather stations are located with black square dots. 


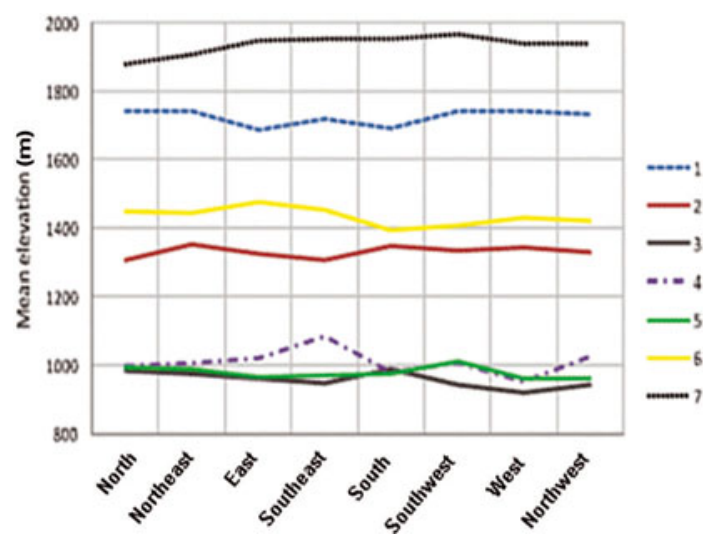

Fig. 7. Mean elevation as a function of aspect for each sub-region. (See Table 4 for region.)

347 selected glaciers. As for several other regions where such analysis has been performed (e.g. for the western Canadian glaciers by Bolch and others, 2010b), a large variability of the changes is found, with an increase in scatter and an increasing relative area loss towards the smallest glaciers. All glaciers in this subsample lost area; the calculated total loss represents $\sim 23 \%$ of the initial area (1948-57). (See section 5.2 for discussion of potential uncertainties.) This area loss is in good agreement with the changes found by Barrand and Sharp (2010) for Yukon (Canada) glaciers. However, it must be noted that the sizeclass distribution might be different in our sample, making the two samples less comparable.

\section{DISCUSSION}

\subsection{Glacier inventory data}

Because of the importance of Alaskan glaciers for global sealevel rise (e.g. Kaser and others, 2006; Radić and Hock, 2010), most of the recent studies on glacier change in Alaska focus on changes in glacier volume, either for selected glaciers (e.g. Arendt and others, 2006; Muskett and others, 2009) or entire mountain ranges (e.g. VanLooy and others, 2006; Berthier and others, 2010). Several of these studies could not exclude certain types of glaciers (e.g. calving or surging) from the analysis to better assess the impact of climate change on mass balance, as outlines of individual glaciers in this region have not been available so far. Moreover, Kaser and others (2006) highlighted the difficulties of determining the mass balance for an entire mountain range from direct measurements of a few selected and often comparably small glaciers. This is only possible when the representativeness of the measurements for the entire region is clear (e.g. Paul and Haeberli, 2008; Fountain and others, 2009). With the outlines now available, we hope that these glacier-specific changes can be calculated.

Though we would have preferred to have all satellite scenes used for the inventory acquired within 1 year (at best) or a few years, we decided to use only the scenes with the best snow conditions (Table 1), in order to minimize the workload and error for manual corrections due to seasonal snow (e.g. Paul and Andreassen, 2009). In the resulting 5 year period, some glaciers (e.g. Columbia Glacier) have shown considerable changes in extent. However, for each glacier outline, the acquisition date is given in the attribute

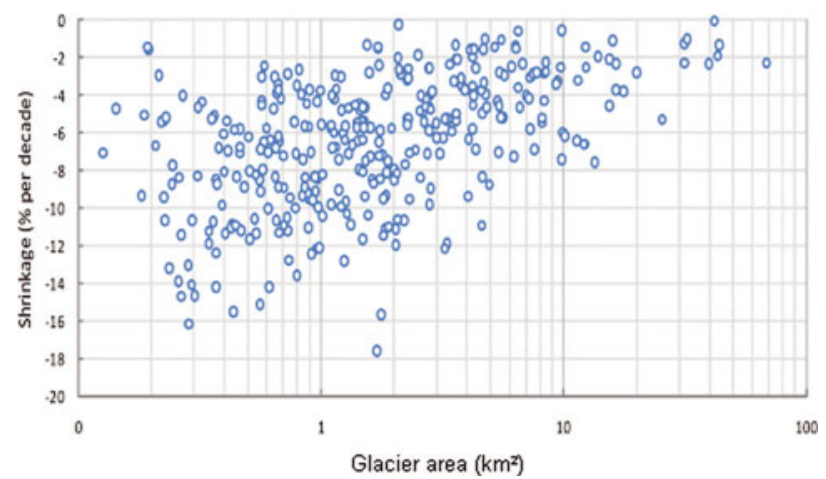

Fig. 8. Glacier shrinkage as a function of initial glacier area (1951-57) for a subset of 347 glaciers.

table, so a proper reference for change assessment can be made. This is of particular importance when dates for the comparison dataset also vary strongly (e.g. Andreassen and others, 2008).

Apart from debris-covered small glaciers or those with an unclear transition to creeping permafrost bodies, the manual correction of the outlines was generally straightforward. This is due to the comparably good contrast of the debris-covered parts with surrounding terrain that results from the low solar elevation at high latitudes. We are aware that the manually corrected outlines of individual (in particular, small) glaciers might have larger errors, but based on previous studies that have determined the accuracy of the outlines (e.g. Paul and others, 2003; Andreassen and others, 2008) we are confident that for most glaciers the accuracy of the derived area is better than $\pm 5 \%$. This does not, however, include differences due to a different interpretation of a glacier entity as a whole (e.g. position of drainage divides, tributaries, attached snowfields). For example, in several cases we may have included perennial snowfields in the inventory, as no bare ice was visible on the satellite images. This is a common problem in all inventories (e.g. DeBeer and Sharp, 2009; Paul and Andreassen, 2009), but these elements can be marked in the attribute table (Paul and others, 2009).

Considering the workload involved in editing the automatically derived outlines, we strongly recommend using automated methods for the initial mapping. This also helps to cover the entire sample of glaciers in a region and to create a consistent and reproducible dataset (Svoboda and Paul, 2009). During manual editing, an inconsistent interpretation and certain degree of generalization is applied, i.e. the same spectral properties of a pixel are always interpreted differently. Though this might not have a large influence on the total area of a glacier, overlays of multiple manual digitizations of the same glacier by the same person revealed a considerable variability ( \pm 1 pixel) of the outline position. Comparing outline overlays from several analysts reveals an even higher variability ( \pm 2 pixels or more), i.e. the digitized extent is not reproducible (GlobGlacier, http://www. globglacier.ch/docs/globgl_deliv7.pdf).

The strong dependence of glacier mean elevation on distance from an arbitrarily chosen point in the ocean is very promising for establishing simple parameterization of either ELA or precipitation in high mountain regions. There is virtually no influence of mean glacier aspect sector on mean elevation within a mountain range (Fig. 7), so compared 


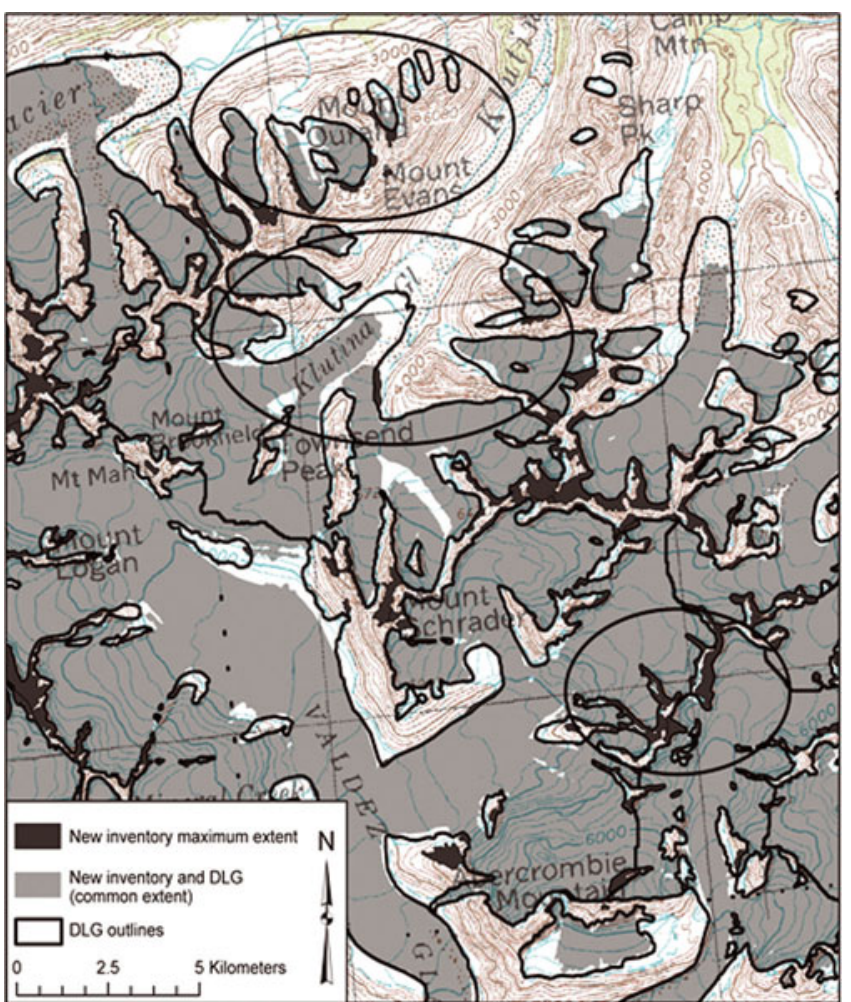

Fig. 9. Illustration of glacier recession in the Valdez district, southern Chugach Mountains. Thick black lines show the DLG glacier outlines, and light grey shading represents the new glacier inventory within the DLG extent, while the dark grey shading depicts the new glacier inventory outside the DLG extent. An example of the DRG (Valdez B-6) is displayed in the background. Black ellipses highlight examples of differences between the two datasets.

with other regions of the world the influence of reduced global radiation receipts for northerly-exposed glaciers is strongly reduced here (Evans, 2006). We assume that this observation can be explained by the influence of the high annual precipitation amounts on the glacier location as well as by the multi-basin origin of many glaciers which often causes differences in the mean aspect of the entire glacier compared to the ablation region.

\subsection{Area change assessment}

To calculate area changes, we manually selected a sample of 347 glaciers, as we found several ambiguities between the DLG outlines and our new inventory (Fig. 9). The example in Figure 9 shows that the DLG outlines do not always match the glacier-covered area on the topographic maps, which implies that they must have been updated somehow. Apart from normal retreat with separation of tributaries, we see glaciers that have been mapped in the DLG but not in our inventory (and vice versa in other regions). This could mean that (1) the glacier has disappeared, (2) we failed to map the glacier because of complete debris cover, or (3) in the DLG, seasonal snow was mapped. Hence, despite changes being clearly visible, the outlines of the DLG can rarely be used for automated change assessment. Also for the manual selection performed here, the error bounds are likely large, as cartographers and glaciologists can have different perceptions of what a glacier is, and the 'truth' can be a matter of debate, even in the field. For the manual selection used here, these cases can be largely excluded so that our estimate of the relative area loss is probably a lower bound.

Though the link between glacier area change and climate change is less straightforward than for mass-balance or length changes, there are also a number of benefits in assessing the former. Area changes can best be derived from satellite sensors and have thus been determined for many regions of the world. This provides interesting insights into the highly variable behavior of glaciers in different regions (e.g. DeBeer and Sharp, 2009; Paul and Andreassen, 2009). They also provide evidence for changes in surface elevation, for example when area is shrinking along the entire perimeter or new rock outcrops appear (e.g. Paul and others, 2007). When this occurs in the accumulation region, the glacier will likely disappear (Pelto, 2010). Area changes of glaciers are thus a valuable proxy for climate-change impact assessment on a global scale.

\section{CONCLUSIONS}

We have presented a new satellite-derived glacier inventory of western Alaska based on nine scenes from Landsat TM acquired between 2005 and 2009. This 5 year period is required because of frequent clouds and seasonal snow on most scenes in the USGS archive. The mapped 8827 glaciers larger than $0.02 \mathrm{~km}^{2}$ cover an area of $16250 \mathrm{~km}^{2}$, a few of them (31) being $>100 \mathrm{~km}^{2}$ and most ( $86 \%$ by number) being $<1 \mathrm{~km}^{2}$. We found a strong relationship between glacier mean elevation and the distance from the ocean, which is related to the decreasing amount of precipitation inland.

We used the band ratio method (TM3/TM5) with a threshold to automatically map all glaciers in the region. Misclassified lakes or water bodies and the omitted debriscovered parts of glaciers were manually corrected. Drainage divides derived from the NED DEM allowed us to derive watersheds and obtain individual glacier entities and topographic inventory parameters. Because of large changes in the ablation zones, the parameter minimum elevation was calculated from the more recent ASTER GDEM. For a selection of 347 glaciers we found an overall recession of $\sim 23 \%$ (by area) between the 1948-57 (DLG) and 2005-09 (Landsat) epochs. Due to several omission and commission errors between the two datasets, a more detailed analysis of the DLG is required before it can be used for further change analyses. In forthcoming studies, we will use the glacier inventory dataset derived here to assess glacier-specific changes. All inventory data are made available in the GLIMS glacier database to enable their use in the required additional studies and assessments.

\section{ACKNOWLEDGEMENTS}

This study was funded by the ESA GlobGlacier project (21088/07/I-EC). Landsat scenes, DLG outlines, DRG maps and the DEM NED were obtained from the USGS (http:// glovis.usgs.gov and http://seamless.usgs.gov). The ASTER GDEM is a product of Japan's Ministry of Economy, Trade and Industry (METI) and NASA and was downloaded from http://www.gdem.aster.ersdac.or.jp and the also used seamless SRTM DEM was downloaded from http://srtm.csi.cgiar. org. We thank E. Berthier for providing data and useful comments on the paper. The comments of the editor, B. Raup, and an anonymous reviewer helped to improve the clarity of the paper. 


\section{REFERENCES}

Albert, T.H. 2002. Evaluation of remote sensing techniques for icearea classification applied to the tropical Quelccaya ice cap, Peru. Polar Geogr., 26(3), 210-226.

Andreassen, L.M., F. Paul, A. Kääb and J.E. Hausberg. 2008. Landsatderived glacier inventory for Jotunheimen, Norway, and deduced glacier changes since the 1930s. Cryosphere, 2(2), 131-145.

Arendt, A. and 7 others. 2006. Updated estimates of glacier volume changes in the western Chugach Mountains, Alaska, and a comparison of regional extrapolation methods. J. Geophys. Res., 111(F3), F03019. (10.1029/2005JF000436.)

Barrand, N.E. and M.J. Sharp. 2010. Sustained rapid shrinkage of Yukon glaciers since the 1957-1958 International Geophysical Year. Geophys. Res. Lett., 37(7), L07051. (10.1029/ 2009GL042030.)

Beedle, M.J. and 7 others. 2008. Improving estimation of glacier volume change: a GLIMS case study of Bering Glacier System, Alaska. Cryosphere, 2(1), 33-51.

Berry, P.A.M., J.D. Garlick and R.G. Smith. 2007. Near-global validation of the SRTM DEM using satellite radar altimetry. Remote Sens. Environ., 106(1), 17-27.

Berthier, E., E. Schiefer, G.K.C. Clarke, B. Menounos and F. Rémy. 2010. Contribution of Alaskan glaciers to sea-level rise derived from satellite imagery. Nature Geosci., 3(2), 92-95.

Bolch, T. and 7 others. 2010a. A glacier inventory for the western Nyainqentanglha Range and Nam Co Basin, Tibet, and glacier changes 1976-2009. Cryosphere, 4(2), 429-467.

Bolch, T., B. Menounos and R. Wheate. 2010b. Landsat-based inventory of glaciers in western Canada, 1985-2005. Remote Sens. Environ., 114(1), 127-137.

Braithwaite, R.J. and S.C.B. Raper. 2009. Estimating equilibriumline altitude (ELA) from glacier inventory data. Ann. Glaciol., 50(53), 127-132.

DeBeer, C.M. and M.J. Sharp. 2009. Topographic influences on recent changes of very small glaciers in the Monashee Mountains, British Columbia, Canada. J. Glaciol., 55(192), 691-700.

DeLorme. 2004. Alaska atlas and gazetteer. Sixth edition. Yarmouth, ME, DeLorme Publishing.

Denton, G.H. and W.O. Field. 1975. Glaciers of the Alaska Range. In Field, W.O., ed. Mountain glaciers of the Northern Hemisphere. Volume 2. Hanover, NH, US Army Corps of Engineers. Cold Regions Research and Engineering Laboratory, 573-620.

Evans, I.S. 2006. Local aspect asymmetry of mountain glaciation: a global survey of consistency of favoured directions for glacier numbers and altitudes. Geomorphology, 73(1-2), 166-184.

Fountain, A.G., M.J. Hoffman, F. Granshaw and J. Riedel. 2009. The 'benchmark glacier' concept - does it work? Lessons from the North Cascade Range, USA. Ann. Glaciol., 50(50), 163-168.

Hayakawa, Y.S., T. Oguchi and Z. Lin. 2008. Comparison of new and existing global digital elevation models: ASTER G-DEM and SRTM-3. Geophys. Res. Lett., 35(17), L17404. (10.1029/ 2008GL035036.)

Kääb, A. and others. 2003. Glacier monitoring from ASTER imagery: accuracy and applications. EARSeL eProc., 2(1), 43-53.

Kaser, G., J.G. Cogley, M.B. Dyurgerov, M.F. Meier and A. Ohmura. 2006. Mass balance of glaciers and ice caps: consensus estimates for 1961-2004. Geophys. Res. Lett., 33(19), L19501. (10.1029/2006GL027511.)

Manley, W.F. 2008. Geospatial inventory and analysis of glaciers: a case study for the eastern Alaska Range. In Williams, R.S., Jr and J.G. Ferrigno, eds. Satellite image atlas of glaciers of the world. Denver, CO, United States Geological Survey, K424-K439. (USGS Professional Paper 1386-K.)

Molnia, B.F. 2007. Late nineteenth to early twenty-first century behavior of Alaskan glaciers as indicators of changing regional climate. Global Planet. Change, 56(1-2), 23-56.
Muskett, R.R. and 6 others. 2009. Airborne and spaceborne DEMand laser altimetry-derived surface elevation and volume changes of the Bering Glacier system, Alaska, USA, and Yukon, Canada, 1972-2006. J. Glaciol., 55(190), 316-326.

Paul, F. and L.M. Andreassen. 2009. A new glacier inventory for the Svartisen region, Norway, from Landsat ETM+ data: challenges and change assessment. J. Glaciol., 55(192), 607-618.

Paul, F. and W. Haeberli. 2008. Spatial variability of glacier elevation changes in the Swiss Alps obtained from two digital elevation models. Geophys. Res. Lett., 35(21), L21502. (10.1029/2008GL034718.)

Paul, F. and A. Kääb. 2005. Perspectives on the production of a glacier inventory from multispectral satellite data in Arctic Canada: Cumberland Peninsula, Baffin Island. Ann. Glaciol., 42, 59-66.

Paul, F., C. Huggel, A. Kääb, T. Kellenberger and M. Maisch. 2003. Comparison of TM-derived glacier areas with higher resolution data sets. EARSeL eProc., 2(1), 15-21.

Paul, F., A. Kääb and W. Haeberli. 2007. Recent glacier changes in the Alps observed from satellite: consequences for future monitoring strategies. Global Planet. Change, 56(1-2), 111-122.

Paul, F., A. Kääb, H. Rott, A. Shepherd, T. Strozzi and E. Volden. 2009a. GlobGlacier: a new ESA project to map the world's glaciers and ice caps from space. EARSeL eProc., 8(1), 11-25.

Paul, F. and 9 others. 2009b. Recommendations for the compilation of glacier inventory data from digital sources. Ann. Glaciol., 50(53), 119-126.

Pelto, M.S. 2010. Forecasting temperate alpine glacier survival from accumulation zone observations. Cryosphere, 4(1), 67-75.

Post, A. and L.R. Mayo. 1971. Glacier dammed lakes and outburst floods in Alaska. USGS Hydrol. Invest. Atlas HA-455.

Post, A. and M.F. Meier. 1980. A preliminary inventory of Alaskan glaciers. IAHS Publ. 126 (Riederalp Workshop 1978 - World Glacier Inventory), 45-47.

Radić, V. and R. Hock. 2010. Regional and global volumes of glaciers derived from statistical upscaling of glacier inventory data. J. Geophys. Res., 115(F1), F01010. (10.1029/ 2009JF001373.)

Raup, B. and 11 others. 2007. Remote sensing and GIS technology in the Global Land Ice Measurements from Space (GLIMS) Project. Comput. Geosci., 33(1), 104-125.

Schiefer, E., B. Menounos and R. Wheate. 2008. An inventory of morphometric analysis of British Columbia glaciers, Canada. J. Glaciol., 54(186), 551-560.

Smith, B. and D. Sandwell. 2003. Accuracy and resolution of shuttle radar topography mission data. Geophys. Res. Lett., 30(9), 1467. (10.1029/2002GL016643.)

Svoboda, F. and F. Paul. 2009. A new glacier inventory on southern Baffin Island, Canada, from ASTER data: I. Applied methods, challenges and solutions. Ann. Glaciol., 50(53), 11-21.

Toutin, T. 2008. ASTER DEMs for geomatic and geoscientific applications: a review. Int. J. Remote Sens., 29(7), 1855-1875.

VanLooy, J., R. Forster and A. Ford. 2006. Accelerating thinning of Kenai Peninsula glaciers, Alaska. Geophys. Res. Lett., 33(21), L21307. (10.1029/2006GL028060.)

Williams, R.S., Jr and J.G. Ferrigno, eds. 2008. Satellite image atlas of glaciers of the world. Denver, CO, United States Geological Survey. (USGS Professional Paper 1386-K.)

World Glacier Monitoring Service (WGMS). 1989. World glacier inventory: status 1988, ed. Haeberli, W., H. Bösch, K. Scherler, G. Østrem and C. Wallén. IAHS (ICSI)/UNEP/UNESCO, World Glacier Monitoring Service, Zürich.

WGMS. 2008. Global glacier changes: facts and figures, ed. Zemp, M., I. Roer, A. Kääb, M. Hoelzle, F. Paul and W. Haeberli. United Nations Environment Programme/World Glacier Monitoring Service, Zürich.

Zhang, J., U.S. Bhatt, W.V. Tangborn and C.S. Lingle. 2007. Climate downscaling for estimating glacier mass balances in northwestern North America: validation with a USGS benchmark 